Ramirez Cheyne Julian (Orcid ID: 0000-0001-5418-7710)

Saldarriaga Wilmar (Orcid ID: 0000-0001-7815-4390)

\title{
FRAGILE X SYNDROME AND CONNECTIVE TISSUE
}

\section{CONNECTIVE TISSUE DEFICITS IN FRAGILE X SYNDROME}

Julián Andrés Ramírez-Cheyne 1

Gustavo Andrés Duque 1

Sebastián Ayala-Zapata 1

Wilmar Saldarriaga-Gil 1

Paul Hagerman 2

Randi Hagerman 2

César Payán-Gómez 3

1 Universidad del Valle, Cali, Colombia.

2 UC Davis MIND Institute, University of California, Davis, United States.

3 Facultad de Ciencias Naturales y Matemáticas, Universidad del Rosario, Bogotá, Colombia.

\section{ACKNOWLEDGMENTS}

To the Department of Morphology of the Universidad del Valle and the MIND Institute

The authors declare neither conflicts of interest nor financial interests.

\section{ABSTRACT}

This is the author manuscript accepted for publication and has undergone full peer review but has not been through the copyediting, typesetting, pagination and proofreading process, which may lead to differences between this version and the Version of Record. Please cite this article as doi: $10.1111 /$ cge.13469

This article is protected by copyright. All rights reserved. 
Fragile $X$ Syndrome is the most common cause of inherited intellectual disabilities and autism spectrum disorders and it is an X-linked disorder in which there is a deficiency of the Fragile X Mental Retardation 1 protein. This protein is crucial in regulating translation of mRNAs related to dendritic maturation and cognitive development. The phenotype of FXS is characterized by neurobehavioral alterations, social deficits, communication difficulties, and findings which suggest an alteration of connective tissue, especially in the ligaments and muscles, cardiovascular system and genitourinary system. Connective tissue connects and supports all other tissues of the body, and is composed of cells and extracellular matrix. Severalproteins have been involved in the connective tissue abnormalities associated with the FXS, such as matrix metalloproteinase 9, which plays an important role in the homeostasis of the extracellular matrix, being a potential therapeutic target for certain tetracycline antibiotics that have shown beneficial effects in FXS. Here we review connective tissue problems described in Fragile X Syndrome.

KEY WORDS: Fragile X Syndrome, Connective tissue, Extracellular Matrix, Extracellular Matrix Proteins.

\section{INTRODUCTION}

Fragile X Syndrome (FXS) is an X-linked disorder with a prevalence of 1 in 2500-5000 males and 1 in 2500-8000 females, and is the most common cause of inherited intellectual disabilities (ID) and autism spectrum disorders (ASD). (1)FXS is caused by an expansion of > 200 CGG repeats (full mutation) in the untranslated 5' region of the gene FMR1 (Fragile X Mental Retardation 1)(2)(1)(3)(4)(5). The hypermethylation of the promoter region in the full mutation leads to silencing of transcription and finally to the absence of FMRP (fragile $\mathrm{X}$ mental retardation protein) (6).

This article is protected by copyright. All rights reserved. 
Phenotypically FXS is characterized by neurobehavioral alterations, such as cognitive dysfunction, involving visual, motor and spatial deficits, hyperactivity, impulsivity, communication problems and ASD (7). However, important physical manifestations are elongated face, large ears, strabismus, pectus excavatum, mitral valve prolapse, excessive laxity of joints, scoliosis and macroorchidism (8)(9)(10), all of them also present in different connective tissue disorders such as Marfanand Ehlers - Danlos syndromes.

The connective tissue is formed by cells and extracellular matrix (ECM) proving the grid of support and connection to all tissues. Cells are separated one from another by the two components of the ECM: one non-fribrillar, which includes glycosaminoglycans, proteoglycans and glycoproteins of adherence (fibronectins and laminin); and another fribrillar that includes multiple types of collagen and elastic fibers, the latter composed of elastin and fibrillin (11).

Cells of tissues associated with connective tissue, contain receptors for ECM, such as the family of the integrins, which are proteins that join extracellularly to fibronectin and intracellularly to actin and myosin. Fibronectins are adherence glycoproteins highly susceptible to proteolysis and are substrates for activated blood coagulation factor VIII. Actin and myosin forms the contractile cytoskeleton. Integrins can produce the stretching of the extracellular fibrils of fibronectin, producing cryptic binding sites and stimulating the polymerization of fibronectin and the assembly of the ECM. Generally, integrins mediate the interaction of cytoskeleton with ECM (11).

A dysfunction or abnormality of the connective tissue in FXS was suggested in 1983, in a description of a boy with dysplasia of the connective tissue and Martin Bell's syndrome (previous name for FXS) (12). Simultaneously numerous young patients with FXS were 
found to have hyperextensible finger joints, linking this feature to the deficit of FMRP in FXS (13). Connective tissue alterations have been subsequently reported specifically in the processes of morphogenesis of the skin and the musculoskeletal, cardiovascular and genitourinary systems in FXS (14)(15)(16). Interestingly, some ECM proteins have been found altered in FXS(17)(18)(19)(20).

\section{FXS AND MUSCULOSKELETAL SYSTEM}

There is an inverse linear relationship between FMRP level and size/length (1\% intraobserver error) of limbs in patients with an FMRP deficit, which supports a possible role of a hypothalamic dysfunction in the growth alterations of FXS(16). Hypothalamic dysfunction is thought to relate to the central nervous system (CNS) changes in FXS including reduced synaptic connectivity and immature dendritic spines(21)(22).There is an increase in head size inversely related with FMRP levels and an increase in brain size with prominence of the frontal lobe (23).

In a study regarding orthopedic aspects of 150 males with FXS, it was found that $50 \%$ had flatfoot, $57 \%$ had hypermobility of the finger joints with metacarpalphangeal extension to 90 degrees and $7 \%$ had scoliosis(24).

Skeletal development and regeneration happen by two general processes: endochondral ossification and intramembranous ossification(25)(26).Endochondral ossification principally happens in long bones, in which primary (diaphyses) and secondary(epiphyses) ossification centers are formed. During this process, the growth plate is formed between diaphyses and epiphysis by the segregation of chondrocytes in different differentiation stages(27). The process of endochondral ossification is regulated by several molecules such as MMPs, including collagenases, gelatinases, among others (28)(29)(30). The role of MMP

This article is protected by copyright. All rights reserved. 
remodeling is crucial in endochondral ossification(31) and MMP9 is controlled by FMRP Different studies have proposed that extrinsic and intrinsic mechanical forces mold bone during morphogenesis(32)(33) . Elastin is required to meet the demands of mechanical stress in vertebrate tissue(34). Hurle et al(35) found that the pattern of arrangement of elastin in embryonic tissues of chick-embryos forms a fibrillar scaffold, generating mechanical stress and allowing a molding effect on the bone formation. Other authors also performed studies with the chick-embryo that revealed expression levels of tropoelastin mRNA early during development, supporting its role in tissue morphogenesis $(36)(37)$

Fibrillin is considered to bea constant component of the elastic matrix, and has been characterized as the fibrillar component associated with amorphous elastin tracts (38). Studies have shown that this fibrillar component precedes the appearance of insoluble and amorphous elastin, suggesting a possible role as a precursor of elastic matrices, facilitating cross-linking between tropoelastin fibers to form elastin tracts (39).

Although the diagnosis of FXS is difficult in newborns and infants because clinical criteria are not clearfor them, radiological and histological descriptions related to alterations of the skeletal system have been reported at both prenatal andpostnatalages and these changes are key to facilitating the early diagnosis of FXS.Hjalgrim et al(40) performed radiographic, histological and histochemical studies in 6 skeletons (4 male, 2 female) of fetuses with FXS(gestational age of 12-14 weeks) obtained from pregnancies of carrier mothers, that were terminated after genetic counseling. The anomalies foundrevolved around the endochondral ossification, part in the spine and part in the jaw, and presumably in the ossification of the nasal bones. The most relevant radiographic findings 
showed that the location and structure of the ossification centers were mostly normal for the individual fetal age in the spine, facial, cranial base and limbsskeleton, except for the nasal bone in 5 cases andthe hands in one case. Histologically, inadequate resorption of notochordal tissue in the vertebral column and cranial base, irregular resorption pattern of cartilaginous tissue in vertebral bodies, altered endochordal ossification in the jaw, delayed apoptosis of ectodermal derived cells, malformations of cartilaginous sellaand acid mucopolysaccharide dysfunction were found.

Kjær et al(41) reviewed the craniofacial profile radiographs and hand radiographs from six FXS males with age between 2 years 9 months and 20 years 3 months. Theyfound some postnatal alterationsthat confirmed several of prenatal findings described above. Radiographic studies showed alterations in the sella, in the cervical spinesuch as fused vertebral bodies and small vertebral archs. At the skeleton of the hand they found distal notches on the first metacarpal bone in some cases. In addition, at both prenatal and postnatal ages, changes in the first finger were discovered, suggesting that an abnormal morphology of this finger can be a key to the early postnatal diagnosis.In allcases there was an abnormal sequence of ossification or abnormal location of the carpal bones. The lunate bone was delayed relative to the trapeze bone, moreover, the latter was located more medially. On radiographs of the hands trapezium and trapezoid bones appeared superimposed, andagain lunate bone was delayed in relation to the trapeze. The hand radiographs showed a delay in skeletal maturation in all cases.

\section{FXS AND CARDIOVASCULAR SYSTEM}

Loehr et al(42) studied 40 patients diagnosed with FXS, who were submitted to a

This article is protected by copyright. All rights reserved. 
complete cardiac evaluation that included physical examination, chest radiography, electrocardiography (ECG) and two-dimensional echocardiography and $M$ mode echocardiography. $18 \%$ of the patients had abnormal aortic root dimensions, and $55 \%$ had mitral valve prolapse. All patients with aortic root dilatation had mitral valve prolapse.Other authors studied 23 patients with FXS and found that $52 \%$ of those had a dilated aortic root and $22 \%$ had mitral valve prolapse. (43)

Another study examined 13 individuals with FXS using standard ECG, ECG-Holter and echocardiography (M-mode, B-mode, doppler mode and color doppler mode) looking for any type of cardiac abnormality. They found that $77 \%$ of these patients had prolapse of the anterior leaflet of the mitral valve, $31 \%$ of whom had posterior leaflet prolapse also. $15 \%$ of the total patients had posterior leaflet prolapse of the aortic valve, $15 \%$ had septal leaflet prolapse of the tricuspid valve, $23 \%$ had mild dilatation of the pulmonary artery, $8 \%$ had mild aortic insufficiency, $69 \%$ had pulmonary valve insufficiency and $77 \%$ had tricuspid valve insufficiency. The authors reaffirmed the high prevalence of mitral valve prolapse in patients with FXS(44). Mitral valve prolapse and aortic root dilation appear at the end of childhood and adolescence in FXS(45). Waldstein et al (20) demonstrated abnormal elastin fibers in the cardiac valves and in the wall of the aorta in a patient with FXS who died suddenly presumably from an arrhythmia.At the autopsy, tubular hypoplasia of the aorta with a postductal coarctation was discovered. The authors found that both the ascending and descending aorta had decreased elastin fibers, in addition to being fragmented, fractured, and separated by an increase in smooth muscle and collagen in the vessel. Acid mucopolysaccharides were modestly decreased from the middle layer to the adventitia, and were decreased significantly in the subintimal. Also, they found thin and fragmented elastin fibers, a shortage of acid mucopolysaccharides and increase in the amount of collagen at the base of the mitral valve. Smaller but similar changes were found in the tricuspid valve. 
Other authors reporteda patient of 87 years of age with FXS who died suddenly due to bronchopneumonia. At the autopsy, a concentric mild cardiac hypertrophy, a moderate left ventricular dilation, a moderate dilation of the left atrium with subendocardial fibrosis and a mild mitral valve degeneration were found. By histology, they confirmed a mucoid degeneration of the mitral leaflets with an excess of acid mucopolysaccharides in the $\operatorname{aorta}(46)$.

Hypertension is not uncommon in men with FXS, however its prevalence has not been studied in detail. It is possible that connective tissue disorders, especially abnormalities in elastic fibers, can affect the resistance of vessel walls, predisposing these patients to have high blood pressure(15). Other authors reported that hypertension may be caused by excessive sympathetic response to stimuli in the environment(47) and certainly the cause of hypertension may be multifactorial in FXS.

\section{FXS AND GENITOURINARY SYSTEM}

Renal disorders have been found in some patients with FXS, which could also be the cause of hypertension.Investigators reported that 3 patients with FXS required nephrectomy due to renal fibrosis and atrophy secondary to the presence of dilated ureters and vesicoureteral reflux(15). Another case was a patient with FXS who hadvesicoureteral reflux without renal damage(15). It is possible that connective tissue dysplasia, described as a cause of cardiovascular abnormalities, could also lead toureteral alterations that predispose to vesicoureteral reflux. There are a few studies about this issue and further investigations are required to confirm this possible association.

The following table summarizes the findings in the musculoskeletal, cardiovascular

This article is protected by copyright. All rights reserved. 
and genitourinary systems in patients with fragile $\mathrm{x}$ syndrome.(Table 1)

\begin{tabular}{|c|c|c|}
\hline System & Findings in Fragile $X$ Syndrome & References \\
\hline \multirow[t]{12}{*}{ Musculoskeletal } & $\begin{array}{l}\text { Inverse linear relationship between } \\
\text { FMRP level and size/length of limbs }\end{array}$ & (16) \\
\hline & Flat foot & (24) \\
\hline & Hypermobility of the finger joints & (24) \\
\hline & Scoliosis & (24) \\
\hline & $\begin{array}{l}\text { Inadequate resorption of notochordal } \\
\text { and cartilaginous tissues in vertebral } \\
\text { column. }\end{array}$ & (40) \\
\hline & $\begin{array}{l}\text { Altered nasal, hand and jaw bones } \\
\text { ossification }\end{array}$ & (40) \\
\hline & Alterations in the sella & \\
\hline & $\begin{array}{l}\text { Fused vertebral bodies and small } \\
\text { vertebral archs }\end{array}$ & (41) \\
\hline & $\begin{array}{l}\text { Distal notches on the first metacarpal } \\
\text { bone }\end{array}$ & (41) \\
\hline & Changes in the first finger & (41) \\
\hline & Abnormal location of the carpal bones & (41) \\
\hline & Delay in skeletal maturation & (41) \\
\hline \multirow[t]{5}{*}{ Cardiovascular } & Abnormal aortic root dimensions & $(42)(43)(44)$ \\
\hline & $\begin{array}{l}\text { Valve prolapse and or insufficiency } \\
\text { mainly mitral, but also aortic, } \\
\text { pulmonary and tricuspid. }\end{array}$ & $(42)(43)(44)$ \\
\hline & $\begin{array}{l}\text { Decreased elastin fibers in aorta and } \\
\text { valves (one case) }\end{array}$ & (20) \\
\hline & $\begin{array}{l}\text { Altered levels of acid } \\
\text { mucopolysaccharides in aorta or valves } \\
\text { (shortage or excess) }\end{array}$ & $(20)(46)$ \\
\hline & Hypertension & $(15)(47)$ \\
\hline Genitourinary & $\begin{array}{l}\text { Dilated ureters and vesicoureteral } \\
\text { reflux }\end{array}$ & $(15)$ \\
\hline
\end{tabular}

Table 1: Findings in the musculoskeletal, cardiovascular and genitourinary systems in patients with fragile $x$ syndrome.

RELATIONSHIP BETWEEN FMRP AND SOME SPECIFIC EXTRACELLULAR MATRIX RELATED

This article is protected by copyright. All rights reserved. 


\section{PROTEINS}

Because FMRP is an RNA binding protein that controls the translation of several hundreds mRNAs, its absence leads to an up-regulation of several proteins, some of them synaptically expressed, mediating the alteration of neuronal signaling and the morphology of the dendritic spines (48). Altered proteins include ECM related proteins that have direct or indirect interaction with FMRP: matrix metalloproteinase 9 (MMP-9), which has been identified as an important element in ECM homeostasis (17)(18); actin (19) and elastin (20). (Figure 1)
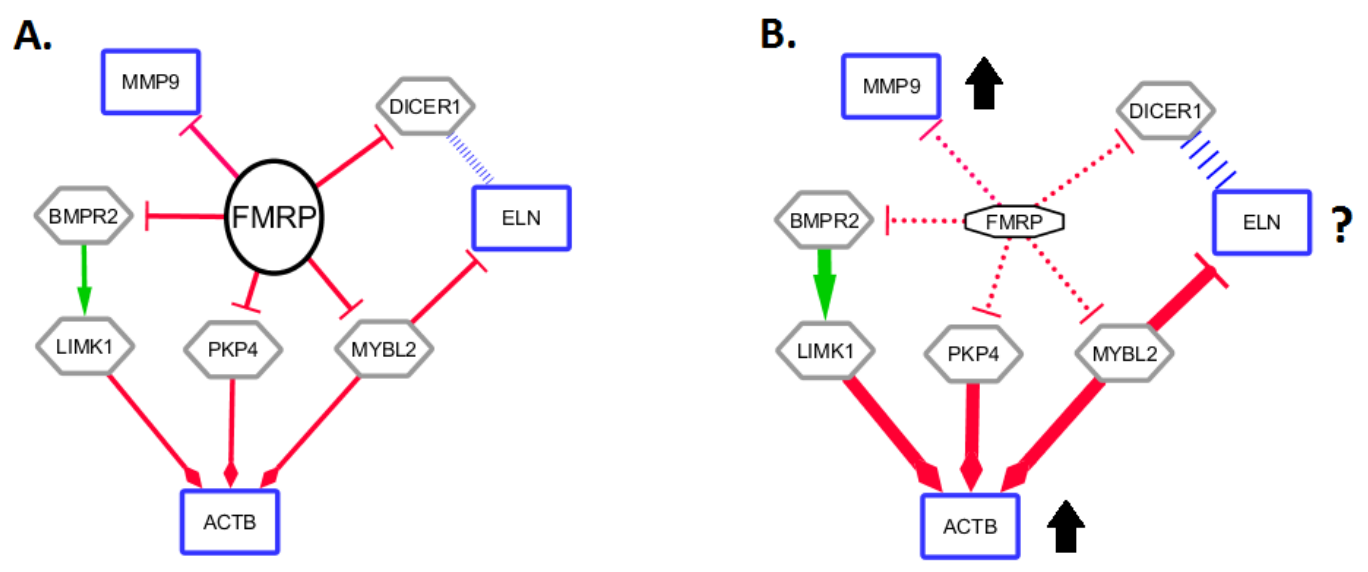

Figure 1. Figure 1. FMRP interaction network in connective tissue. FMRP is a central protein in the normal functioning of connective tissue. $1 \mathrm{~A}$ ) In normal conditions FMRP modulate the amount and activity of matrix proteins. 1B) In connective tissue of $X$ Fragile patients the down-regulation of FMRP expression produces an over/expression of connective tissue proteins regulated by FMRP. Gray hexagons represent the intermediary proteins in the regulation of connective tissue proteins. Blue squares show connective

This article is protected by copyright. All rights reserved. 
tissue proteins. The green arrow means activation, red T arrows means inactivation or down-regulation of protein levels, diamond arrows means induction of remodeling, blue vertical slash arrow means complex and non-complete established relation. The figure was built using Cytoscape 3.6.0 (49)

FMRP and MMP9: A possible therapeutic target of Minocycline.

Pro-MMP-9 is secreted into the ECM in response to synaptic stimulation. Once at the ECM, proteolytic cleavages transform pro-MMP-9 (precursor form) into endopeptidase MMP-9 (active form) (50)(51). The active form is responsible for regulating the pericellular environment through cleavage of different protein components. This function has been associated with synaptic changes that occur in the processes of learning and memory (52).

FMRP regulates the translation of many proteins important for synapticplasticity (48). Elevations of MMP-9 have been documented in blood in patients with FXS and these elevations are lowered by minocycline treatment (48).

The extracellular location of MMP-9 makes it particularly attractive as a potential target for pharmacological therapeutic intervention, because it is accessible to inhibitors that can decrease its activity(48). Minocycline is a tetracycline antibiotic commonly used to treat acne vulgaris (53)but has had success as a neuroprotective in animal models of multiple sclerosis(54), Huntington's disease(55)(56), amyotrophic lateral sclerosis (57) and $\operatorname{FXS}(18)(58)$.

Studies with minocycline have shown that this drug promotes maturation of dendritic spines and improves behavioral performance in FMR1 knockout mice, making this drug a

This article is protected by copyright. All rights reserved. 
potential pharmacotherapy for FXS(18). Other clinical studies (without molecular evidence) have indicated that some patients have benefited from the treatment with minocycline (59)(60)(61).

\section{FMRP and Actin}

It has been shown that FMRP regulates actin organization and neurite outgrowth via the armadillo protein PKP4. High levels of PKP4 were found in mouse embryonic fibroblasts lacking FMRP (Fmr1-), and the actin cytoskeleton was markedly reorganized with a reduction of stress fibers and the F-actin/G-actin ratios, compared with fibroblasts in which the re-expression of the protein was induced(19). In addition, it has been shown that mRNA encoding bone morphogeneticprotein type II receptor (BMPR2) is a target of FMRP and that loss of FMRP leads to increases in BMPR2message and protein levels, resulting in activation of LIM kinase 1 (LIMK1),a component of the noncanonical BMP signal transduction pathway that stimulates actin reorganizationto promote neurite outgrowth and synapse formation. (62)

\section{FMRP and Elastin}

FMRP is part of the RNA-induced silencing complex (RISC) which is necessary in the negative posttranscriptional regulation of gene expression through translational repression by the AGO proteins family or through specific mRNA cleavage. Several studies strongly suggest that the microRNAs (miRNA) are involved in the regulation mediated by FMRP (63). It has been found that phosphorylated FMRP inhibits DICER binding capacity, leading to the accumulation of miRNAs precursors and possibly lack of activation of miRNAs (64). On the other hand, it has been suggested that the families of miRNAs miR-29 and miR-15, are involved in the down-regulation of elastin in the adult aorta (65).

This article is protected by copyright. All rights reserved. 
FMRP is a RNA-binding protein whose function has been related with the transport of specific mRNAs and their translational control(66). FMRP-mRNAs complexes are formed by the presence of RNA recognition elements (RREs) in the mRNAs and these RREs interact with the RNA binding domains of FMRP. Ascano et al, using a PAR-CLIP methodology in HEK293 cells identified mRNAs with high ability to bind to FMRP. When they explored the level of selected proteins as a function of FMRP expression they found a $30 \%$ reduction in proteins levels with the up-regulation of $\operatorname{FMRP}(67)$. Interestingly, an important regulator of the expression of collagen and elastin in vascular smooth muscle cells, called MYB proto-oncogene like 2 (Mybl2), was present in the list of mRNA with the ability to bind to $\operatorname{FMRP}(68)$.

\section{CONCLUSION}

Many of the physical features of FXS are similar to those of other connective tissue disorders and connective tissue alterations have been reported specifically in the processes of morphogenesis of the skin, musculoskeletal, cardiovascular and genitourinary systems in FXS. Also, some of the altered proteins in FXS are components of ECM. So, relationship between FMRP and proteins of the ECM should be further investigated.

\section{REFERENCES}

1) Tassone F, long KP, Tong T-H, Lo J, Gane LW, Berry-Kravis E, et al. FMR1 CGG allele size and prevalence ascertained through newborn screening in the United States. Genome Med. 2012;4(12):100

2) Verkerk AJ, Pieretti M, Sutcliffe JS, Fu YH, Kuhl DP, Pizzuti A, et al. Identification of a gene (FMR-1) containing a CGG repeat coincident with a breakpoint cluster region exhibiting length variation in fragile X syndrome. Cell. 1991 May;65(5):905-14.

3) Chonchaiya W, Schneider A, Hagerman R. Fragile X: A family of disorders. 
AdvPediatr. 2009;56:165-86.

4) Levenga J, de Vrij FM, Oostra BA, Willemsen R. Potential therapeutic interventions for fragile X syndrome. Trends Mol Med. 2010;16:516-27.

5) Fu YH, Kuhl DP, Pizzuti A, Pieretti M, Sutcliffe JS, Richards S, Verkerk AJ, Holden JJ, Fenwick RG Jr, Warren ST, et al. Variation of the CGG repeat at the fragile $X$ site results in genetic instability: resolution of the Sherman paradox. Cell. 1991;67:1047-58.

6) Darnell JC, Van Driesche SJ, Zhang C, Hung KYS, Mele A, Fraser CE, et al. FMRP stalls ribosomal translocation on mRNAs linked to synaptic function and autism. Cell. 2011 Jul;146(2):247-61.

7) Jacobs PA, Glover TW, Mayer M, Fox P, Gerrard JW, Dunn HG, Herbst D. X-linked mental retardation: a study of 7 families. Am J Med Genet. 1980;7:471-89.

8) Hagerman R, Kemper M HM. Learning disabilities and attentional problems in boys with the fragile X syndrome. Am J Dis Child. 1985;139:674-8.

9) Sudhalter V, Scarborough HS, Cohen IL. Syntactic delay and pragmatic deviance in the language of fragile X males. Am J Med Genet. 1991; 30:493-7.

10) Baumgardner T, Reiss A, Freund L, Abrams M. Specification of the neurobehavioral phenotype in males with fragile X syndrome. Pediatrics. 1995;95:744-52.

11) Kierszenbaum AL, Tres LL. 4th edition. Histology and Cell Biology. An Introduction to Pathology. Philadelphia. Elsevier. 2016.

12) Opitz JM, Westphal JM Daniel A. Discovery of a connective tissue dysplasia in the Martin-Bell syndrome. Am J Med Genet. 1984;17:101-9.

13) Riddle JE, CheemaA, Sobesky WE, Gardner SC, Taylor AK, Pennington BF, et al. Phenotypic involvement in females with FMR1 gene mutation. Am J Ment Retard. 1998;102(6):590-601.

14) Sandikcioglu M, Mølsted K, Kjaer I. The prenatal development of the human nasal

This article is protected by copyright. All rights reserved. 
and vomeral bones. J Craniofac Genet Dev Biol. 1994;14:124-34.

15) Hagerman RJ, Hagerman PJ. Fragile X Syndrome: Diagnosis, treatment, and research. 3rd ed. Baltimore. Johns Hopkins Univ Press. 2002; Chapter 1.

16) Loesch DZ, Huggins RM, Bui QM, Taylor AK, Hagerman RJ. Relationship of deficits of FMR1 gene specific protein with physical phenotype of fragile $X$ males and females in pedigrees: a new perspective. Am J Med Genet Part A. 2003;118A(2):127-34.

17) Shapiro SD. Matrix metalloproteinase degradation of extracellular matrix: biological consequences. CurrOpin Cell Biol. 1998;10:602-8.

18) Bilousova T, Dansie L, Ngo M, Aye ,J, Charles J, Ethell D, et al. Minocycline promotes dendritic spine maturation and improves behavioural performance in the fragile $X$ mouse model. J Med Genet. 2009;46:94-102.

19) Nolze A, Schneider J, Keil R, Lederer M, Hüttelmaier S, Kessels MM, Qualmann B, Hatzfeld M. FMRP regulates actin filament organization via the armadillo protein p0071. RNA. 2013;19:1483-96.

20) Waldstein G, Hagerman R. Aortic hipoplasia and cardiac valvular abnormalities in a boy with fragile X syndrome. Am J Med Genet. 1988;30:83-98.

21) Weiler IJ, Wreenough WT. Synaptic synthesis of the Fragile X protein: Possible involvement in synapse maturation and elimination. AmJ Med Genet. 1999;83:248522.

22) LoeschDZ, Huggins RM, Hoang NH. Growth in stature in fragile $X$ families: a mixed longitudinal study . Am J Med Genet. 1995; 58(3) : 249-56.

23) Reiss AL, Eliez S, Smith JE, Patwardhan A, Haberecht M. Brain imaging in neurogenetic conditions: Realizing the potential of behaviouralneurogenetics research. MRDD Res Rev. 2000;6:186-97.

24) Davids JR, Hagerman RJ, Eilert RE. Orthopaedic aspects of fragile-X syndrome. J Bone. JtSurg Am. 1990;72(6):889-96.

This article is protected by copyright. All rights reserved. 
25) Tuan RS. Biology of developmental and regenerative skeletogenesis. ClinOrthopRelat Res. 2004;105-17.

26) Yang Y. Skeletal morphogenesis during embryonic development. Critical reviews in eukaryotic gene expression. Crit Rev Eukaryot Gene Expr. 2009;19(3):197-218.

27) Ortega N, Behonick D WZ. Matrix remodeling during endochondral ossification. Trends Cell Biol. 2004;14(2):86-93.

28) Blair H. Mechanisms balancing skeletal matrix synthesis and degradation. Biochem J. 2002;364:329-41.

29) Flenniken AM, Williams BR. Developmental expression of the endogenous TIMP gene and a TIMP-lacZ fusion gene in transgenic mice. Genes Dev. 1990;4:1094-106.

30) Huang W, Li WQ, Dehnade F, Zarafullah, M. Tissue inhibitor of metalloproteinases-4 (TIMP-4) gene expression is increased in human osteoarthritic femoral head cartilage. J Cell Biochem. 2002;85:295-303.

31) Blavier L, Delaisse J. Matrix metalloproteinases are obligatory for the migration of preosteoclasts to the developing marrow cavity of primitive long bones. J Cell Sci. 1995;108:3649-59.

32) Harris, AK, Stopak D and Wild P. Fibroblast traction as a mechanism for collagen morphogenesis. Nature. 1981;290, 249-251

33) Stopak D and Harris AK. Connective tissue morphogenesis by fibroblast traction. Dev. Biol. 1982;90, 383-398

34) Sage $H$ and Gray WR. Studies on the evolution of elastin. I. Phylogenetic distribution. Comp. Biochem. Physiol. 1979;64B, 313-327

35) Hurle J, Corson G, Daniels K, Rebecca S, Reiter RS, Sakai LY, Solursh M. Elastin exhibits a distinctive temporal and spatial pattern of distribution in the developing chick limb in association with the establishment of the cartilaginous skeleton. J Cell Sci. 1994; 107: 2623-2634.

This article is protected by copyright. All rights reserved. 
36) Selmin O, Volpin D and Bressan GM. Changes of cellular expression of mRNA for tropoelastin in the intraembryonic arterial vessels of developing chick revealed by in situ hybridization. Matrix. 1991;11, 347- 358

37) Holzenberger $M$, Lièvre $C A$ and Robert $L$. Tropoelastin gene expression in the developing vascular system of the chicken: an in situ hybridization study. Anat. Embryol. 1993;188, 481-492

38) Sakai LY, Keene DR and Engvall E. Fibrillin, a new 350-kD glycoprotein, is a component of extracellular microfibrils. J. Cell Biol. 1986;103, 2499-2509.

39) Cleary EG and Gibson MA. Elastin-associated microfibrils and microfibrillar proteins. Int. Rev. Conn. Tiss. Res. 1983;10, 97-209

40) Hjalgrim H, Fisher Hansen B, Brondum-Nielsen K, Nolting D, Kjaer I. Aspects of skeletal development in fragile X syndrome fetuses. Am J Med Genet. 2000 Nov;95(2):123-9.

41) Kjær I, Hjalgrim H, Russell BG. Cranial and Hand Skeleton in Fragile X Syndrome. Am J Med Genet. 2001;100:156 \pm 161 .

42) Loehr J, Synhorst D, Wolfe RR, Hagerman RJ. Aortic Root Dilatation and Mitral Valve Prolapse in the Fragile X Syndrome. Am J Med Genet. 1986;23:189-94.

43) Sreeram N, Wren C, Bhate M, Robertson P, Hunter S. Cardiac abnormalities in the fragile X syndrome. Br Heart J. 1989 Mar;61(3):289-91.

44) Puzzo A, Fiamma G, Rubino VE, Gagliano PA, Giordano G, Russo L, Aloisi B, Manzoli U. Cardiovascular aspects of Martin-Bell syndrome. Cardiologia. 1990;35(10):85762.

45) Crabbe L, Hornstein L, Bensky A, Schwartz D. Cardiovascular Abnormalities in Children With Fragile X Syndrome. Pediatrics. 1993;91:714-5.

46) Sabaratnam M. Pathological and neuropathological findings in two males with fragile-X syndrome. J Intellect Disabil Res. 2000;44:81-5.

This article is protected by copyright. All rights reserved. 
47) Miller LJ, Mclntosh DN, McGrath J, Shyu V, Lampe M, Taylor AK, Tassone F, Neitzel K, Stackhouse T, Hagerman RJ. Electrodermal responses to sensory stimuli in individuals with fragile X syndrome: a preliminary report. Am J Med Genet. 1999;83(4):268-79.

48) Dziembowska M, Pretto DI, Janusz A, Kaczmarek L, Leigh MJ, Gabriel N, et al. High MMP-9 activity levels in fragile $X$ syndrome are lowered by minocycline. Am J Med Genet Part A. 2013;161(8):1897-903.

49) Shannon P, Markiel A, Ozier O, Baliga NS, Wang JT, Ramage D, Amin N, Schwikowski B, Ideker T. Cytoscape: a software environment for integrated models of biomolecular interaction networks. Genome Research 2003; 13(11):2498-504)

50) Bruno MA, Cuello AC. Activity-dependent release of precursor nerve growth factor, conversion to mature nerve growth factor, and its degradation by a protease cascade. Proc Natl AcadSci U S A. 2006;103(17):6735-40.

51) Dziembowska M, Milek J, Janusz A, Rejmak E, Romanowska E, Gorkiewicz T, et al. Activity-dependent local translation of matrix metalloproteinase-9. J Neurosci. 2012;32(42):14538-47.

52) Wang X, Bozdagi O, Nikitczuk JS, Zhai ZW, Zhou Q, Huntley GW. Extracellular proteolysis by matrix metalloproteinase-9 drives dendritic spine enlargement and long-term potentiation coordinately. Proc Natl AcadSci U S A. 2008;105(49):195205.

53) Garner S, Eady E, Popescu C, Newton J, Li W. Minocycline for acne vulgaris: Efficacy and safety. Cochrane Database Syst Rev. 2003;CD002086.

54) Chen X, Ma X, Jiang Y, Pi R, Liu Y, Ma L. The prospects of minocycline in multiple sclerosis. J Neuroimmunol. 2011;235:1-8.

55) Wang X, Zhu S, Drozda M, Zhang W, Stavrovskaya I, Cattaneo E, et al. Minocycline inhibits caspase-independent and -dependent mitochondrial cell death pathways in 
models of Huntington's disease. Proc Natl AcadSci U S A .2003;100:10483-7.

56) Kalonia H, Mishra J, Kumar A. Targeting neuro-inflammatory cytokines and oxidative stress by minocycline attenuates quinolinic- acid-induced Huntington's disease-like symptoms in rats. Neurotox Res. 2012;22:310-20.

57) Kriz J, Nguyen M, Julien J. Minocycline slows disease progression in a mouse model of amyotrophic lateral sclerosis. Neurobiol Dis. 2002;10:268-78.

58) Siller S, Broadie K. Neural circuit architecture defects in a Drosophila model of Fragile $X$ syndrome are alleviated by minocycline treatment and genetic removal of matrix metalloproteinase. Dis Model Mech. 2011;4:673-85.

59) Leigh $M$, Nguyen $D, M u ~ Y$, Winarni T, Schneider A, Chechi T, et al. A randomized double-blind, placebo-controlled trial of minocycline in children and adolescents with Fragile X Syndrome. J Dev BehavPediatr. 2013;34:147-55.

60) Paribello C, Tao L, Folino A, Berry-Kravis E, Tranfaglia M, Ethell IM, et al. Open-label add-on treatment trial of minocycline in fragile $X$ syndrome. BMC Neurol. 2010;10:91.

61) Utari A, Chonchaiya W, Rivera S, Schneider A, Hagerman R, Faradz S, et al. Side effects of minocycline treatment in patients with fragile $X$ syndrome and exploration of outcome measures. Am J Intellect Dev Disabil. 2010;115:433-43.

62) Kashima R, Roy S, Ascano M, Martinez-Cerdeno V, Ariza-Torres J, Kim S, et al. Augmented noncanonical BMP type II receptor signaling mediates the synaptic abnormality of fragile X syndrome. Sci Signal. 2016;9(431):ra58.

63) Li Y, Lin L, Jin P. The microRNA pathway and fragile $X$ mental retardation protein. BiochimBiophysActa. 2008;1779(11):702-5.

64) Cheever A and Ceman S. Translation regulation of mRNAs by the fragile $X$ family of proteins through the microRNA pathway. RNA Biol. 2009;6(2):175-8.

65) Ott CE, Grünhagen J, Jäger M, Horbelt D, Schwill S, Kallenbach K, et al. MicroRNAs

This article is protected by copyright. All rights reserved. 
differentially expressed in postnatal aortic development downregulate elastin via 3' UTR and coding-sequence binding sites. PLoS One. 2011;6(1):e16250.

66) Santoro MR, Bray SM, Warren ST. Molecular mechanisms of fragile $X$ syndrome: A twenty-year perspective. Annu Rev Pathol. 2012; 7:219-245

67) Ascano M Jr, Mukherjee N, Bandaru P, Miller JB, Nusbaum JD, Corcoran DL, Langlois C, Munschauer M, Dewell S, Hafner M, Williams Z, Ohler U, Tuschl T. FMRP targets distinct mRNA sequence elements to regulate protein expression. Nature. 2012;492(7429):382-6.

68) Hofmann CS, Wang X, Sullivan CP, Toselli P, Stone PJ, McLean SE, Mecham RP, Schreiber BM, Sonenshein GE. B-Myb represses elastin gene expression in aortic smooth muscle cells. J BiolChem. 2005;280(9):7694-701.

This article is protected by copyright. All rights reserved. 


\section{Fragile X Syndrome and Connective Tissue}

The phenotype of FXS is characterized by neurobehavioral alterations, social deficits, communication difficulties, and findings which suggest an alteration of connective tissue, especially in the ligaments and muscles, cardiovascular system and genitourinary system. Connective tissue connects and supports all other tissues of the body, and is composed of cells and extracellular matrix. Several proteins have been involved in the connective fissue abnormalities associated with the fragile $X$ syndrome.

Findings in the musculoskeletal, cardiovascular and genitourinary systems in patients with Fragile $X$ Sydrome

System

Musculoskeletal

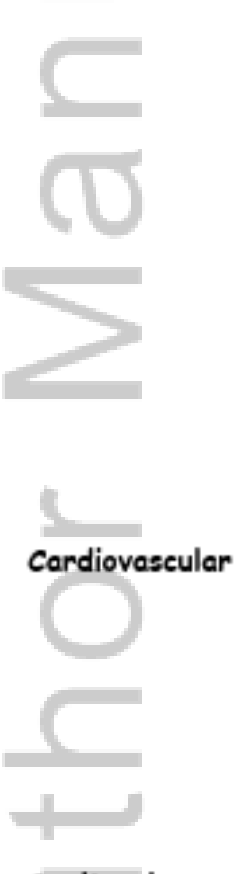

Genitourinary

\section{Findings in Fragile $X$ Syndrome}

Inverse linear relationship between FMRP level and size/length of limbs

Flat foot

Hypermobility of the finger joints

Scoliosis

Inadequate resorption of notochordal and cartilaginous tissues in vertebral column.

Altered nasal, hand and jaw bones ossification

Alterations in the sella

Fused vertebral bodies and small vertebral archs

Distal notches on the first metacarpal bone

Changes in the first finger

Abnormal location of the carpal bones

Delay in skeletal maturation

Abnormal aortic root dimensions

Valve prolapse and or insufficiency mainly mitral, but also aortic, pulmonary and tricuspid.

Decreased elastin fibers in aorta and valves (one case)

Altered levels of acid mucopolysaccharides in aorta

or valves (shortage or excess)

Hypertension

Dilated ureters and vesicoureteral reflux
Fragile X Mental Retardation Protein interaction network in connective tissue

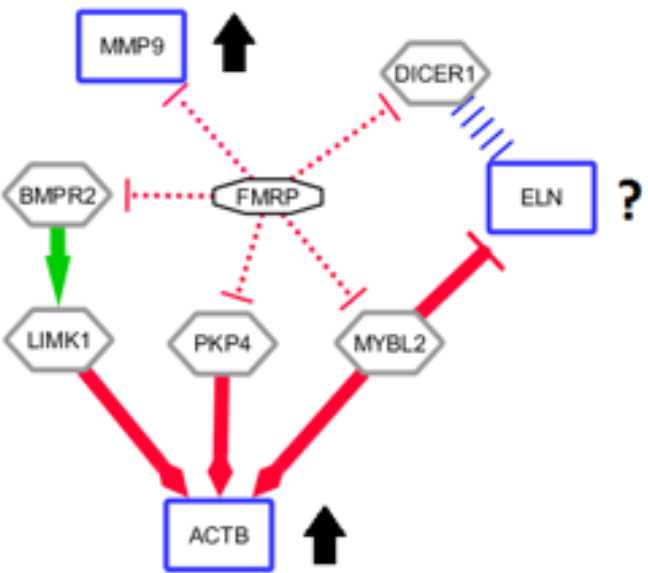

In connective tissue of $X$ Fragile patients the downregulation of FMRP expression produces an over expression of connective tissue proteins regulated by Fragile $X$ Mental Retardation Protein.

Gray hexagons represent the intermediary proteins in the regulation of connective tissue proteins. Blue squares show connective tissue proteins. The green arrow means activation, red $T$ arrows means inactivation or downregulation of protein levels, diamond arrows means induction of remodeling. blue vertical slash arrow means complex and non-complete established relation.

graphical abstract def.PNG 


\section{University Library}

\section{- M M N E R VA A gateway to Melbourne's research publications}

Minerva Access is the Institutional Repository of The University of Melbourne

Author/s:

Ramirez-Cheyne, JA;Duque, GA;Ayala-Zapata, S;Saldarriaga-Gil, W;Hagerman,

P;Hagerman, R;Payan-Gomez, C

Title:

Fragile $\mathrm{X}$ syndrome and connective tissue dysregulation

Date:

2019-02-01

Citation:

Ramirez-Cheyne, J. A., Duque, G. A., Ayala-Zapata, S., Saldarriaga-Gil, W., Hagerman, P., Hagerman, R. \& Payan-Gomez, C. (2019). Fragile X syndrome and connective tissue dysregulation. CLINICAL GENETICS, 95 (2), pp.262-267. https://doi.org/10.1111/cge.13469.

Persistent Link:

http://hdl.handle.net/11343/285115 